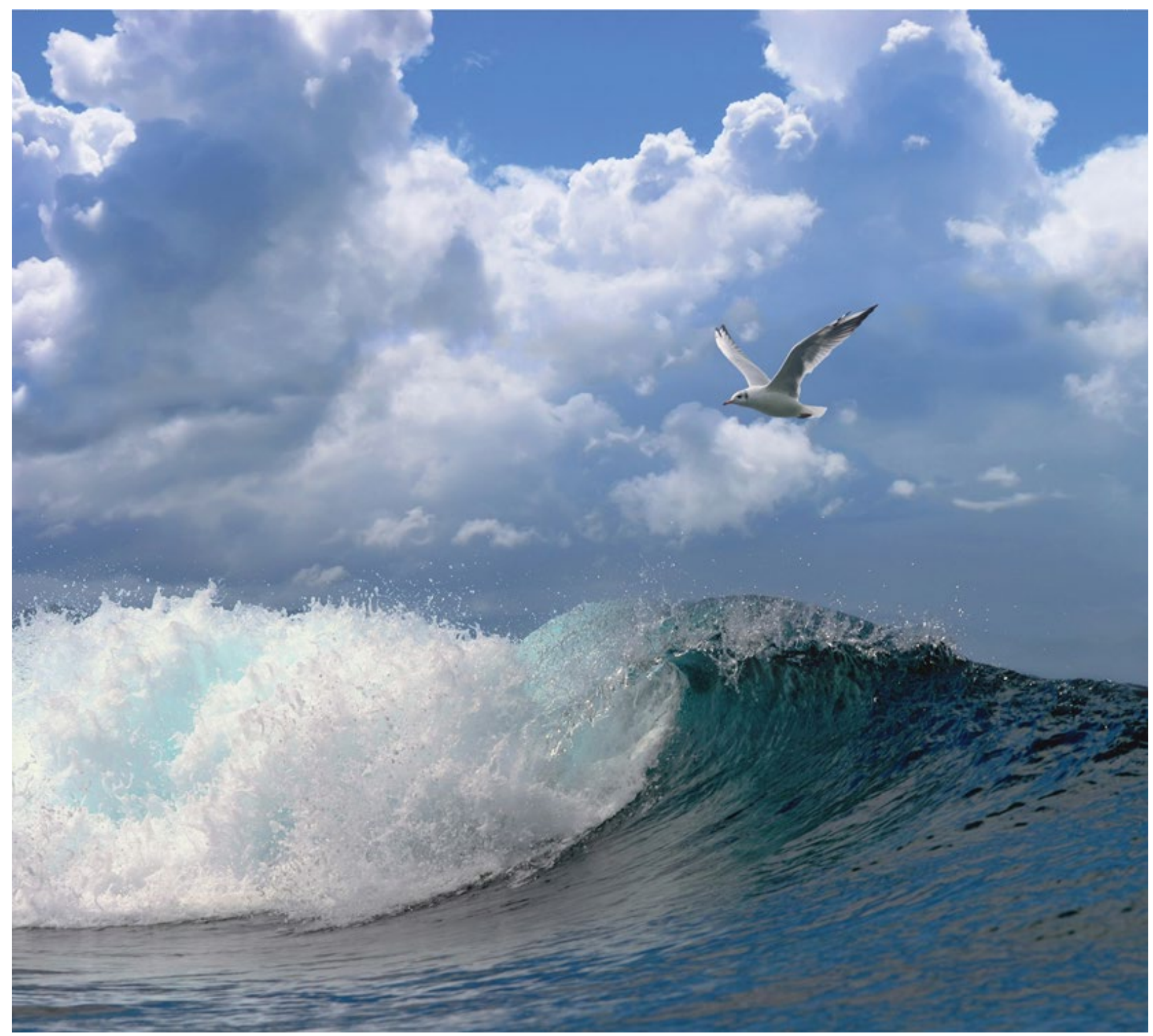

\title{
Flyshoot fishery in the Plaice Box
}




\section{Flyshoot fishery in the Plaice Box}

Author(s): J.C. van Rijssel 
Keywords: Flyshoot, Plaice Box, SSC, Sole, Plaice, Gurnard.

Client: $\quad$ CVO (Coöperatieve Visserij Organisatie)

T.a.v. Geert Meun

P.O. Box 59

8320 AB Urk

This report can be downloaded for free from https://doi.org/10.18174/541159

Wageningen Marine Research provides no printed copies of reports

Wageningen Marine Research is ISO 9001:2015 certified.

\section{(C) Wageningen Marine Research}

Wageningen Marine Research, an institute within the legal entity Stichting Wageningen Research (a foundation under Dutch private law) represented by Dr.ir. J.T. Dijkman, Managing director

KvK nr. 09098104, WMR BTW nr. NL 8113.83.696.B16.

Code BIC/SWIFT address: RABONL2U IBAN code: NL 73 RABO 0373599285
Wageningen Marine Research accepts no liability for consequential damage, nor for damage resulting from applications of the results of work or other data obtained from Wageningen Marine Research. Client indemnifies Wageningen Marine Research from claims of third parties in connection with this application.

All rights reserved. No part of this publication may be reproduced and / or published, photocopied or used in any other way without the written permission of the publisher or author. 


\section{Contents}

Flyshoot fishery in the Plaice Box

Summary

$1 \quad$ Introduction

$2 \quad$ Assignment

$3 \quad$ Materials and Methods $\quad 8$

$\begin{array}{llr}\text { Results } & 9\end{array}$

5 Conclusions $r$\begin{tabular}{l}
13 \\
\hline
\end{tabular}

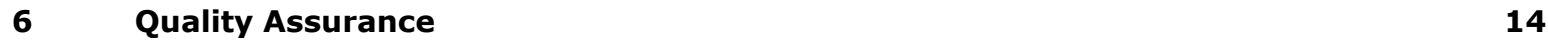

$\begin{array}{lr}\text { References } & 15\end{array}$

$\begin{array}{lr}\text { Justification } & 16\end{array}$

$\begin{array}{llr}\text { Annex } 1 & \text { Title annex } & 14\end{array}$ 


\section{Summary}

The European Union Technical measures are a broad set of rules which govern how, where and when fishermen may fish. The technical measures regulations in the EU need to be modernized in light of the reformed Common Fisheries Policy. To this effect, the European Commission has put forward a new framework proposal for technical conservation measures.

One of the matters that will be discussed within this framework is the fishery within the Plaice Box. The flyshoot fishery (SSC) is one of the fisheries still allowed in the Plaice Box provided that the mesh size is larger than $100 \mathrm{~mm}$. To estimate the actual effort and biomass caught per species, at the request of VisNed, Wageningen Marine Research calculated the number of hours fished per gridcell in the Plaice Box and the Greater North Sea and the biomass caught per species per year for the period 2010-2019.

The largest effort of the flyshoot fishery is in the southern part of the Greater North Sea. The flyshoot fishery is also active in the Plaice Box with the largest effort at the outer periphery of the Plaice Box. The catches of the flyshoot fishery mainly consist of tub gurnard, dab and plaice. The percentage of plaice (and sole) per year compared to the total catch is $14.6 \%$. 


\section{Samenvatting}

Over de nieuwe EU Verordening Technische Maatregelen vindt in Europees verband nader overleg plaats. De nieuwe Verordening is een raamwerk waarbij een aantal technische maatregelen nader ingevuld moeten worden. Hierbij vindt er onder andere overleg plaats over visserijen binnen de Scholbox.

De flyshoot (SSC) visserij is een van de visserijen die actief is in de Scholbox. Dit is toegestaan mits een maaswijdte van ten minste $100 \mathrm{~mm}$ wordt gebruikt. Vanwege het bovenstaande heeft Wageningen Marine Research in opdracht van VisNed de inspanning van flyshooters in de Scholbox en daarbuiten in kaart gebracht. Daarnaast is een overzicht van de vangsten van de flyshooters gemaakt over de periode 2010-2019 met de gemiddelde vangst per soort per jaar.

De grootste inspanning (aantal visuren) vind plaats in de zuidelijke Noordzee. The flyshoot visserij is ook actief in de Scholbox met de hoogste inspanning aan de buitenzijde van de Scholbox. De vangsten van de flyshoot visserij bestaan voornamelijk uit rode poon, schar en schol. Het percentage van schol (en tong) per jaar ten opzichte van de totale vangst is $14,6 \%$. 


\section{Introduction}

The European Union Technical measures are a broad set of rules which govern how, where and when fishermen may fish. They are established for all European sea basins, but they differ considerably from one basin to another, in accordance with the regional conditions. The technical measures regulations in the EU need to be modernized in light of the reformed Common Fisheries Policy. To this effect, the European Commission has put forward a new framework proposal for technical conservation measures.

One of the matters that will be discussed within this framework is the fishery within the Plaice Box. To allow the recovery of juvenile plaice, bottom trawl vessels with an engine power of $<300 \mathrm{hp}$ are allowed to fish in the Plaice Box while bottom trawl vessels with an engine power of $>300 \mathrm{hp}$ are not. This means that several fisheries are allowed to fish within the Plaice Box including flyshoot, Scottish seine fishery (SSC). Flyshooters apply a deviating fishing technique in comparison with the other demersal fisheries. This fishing technique is developed to catch both pelagic and demersal fish, while the time the fish are in the net is as short as possible. Long lines are attached to the net doors. The net is set in a circle or square by the fisherman. Then, when hauling the lines, the circle/square closes and the lines herd the fish towards the middle of the circle/square where they are caught in the net (van der Reijden et al., 2014). The flyshoot fishery is a seasonal fishery targeting mullet, tub gurnard, squid, mackerel, plaice, dab, whiting and cod. Flyshoot vessels fish in the North Sea in spring and summer. In the autumn and winter the vessels move towards warmer waters in the Channel.

For this report, we calculated the effort of the Dutch flyshoot fisheries in the Greater North Sea with an emphasis on the Plaice Box. For the Plaice Box, we also calculated the total amount of biomass and percentages of species caught per year from 2010-2019. 


\section{Assignment}

Several fisheries including flyshoot are allowed to fish within in the Plaice Box. To estimate the actual effort and biomass caught per species, at the request of VisNed, Wageningen Marine Research calculated the number of hours fished per gridcell in the Plaice Box and the Greater North Sea and the biomass caught per species per year for the period 2010-2019. 


\section{Materials and Methods}

The Dutch 'Vessel Monitoring System' (VMS) has been used since January 12000 and is controlled by the Dutch Food Safety Authority. VMS is nowadays a standard tool of fisheries monitoring and control worldwide and these data can be used to analyse the spatial dynamics of the fishery fleets. Vessel with a length of $>15 \mathrm{~m}$ are obliged to have a VMS on board and from 2012 onwards this applies to vessels with a length of $>12 \mathrm{~m}$. The VMS ensures the regular submission of the exact locations (longitude, latitude, speed and heading) of each vessel to a centralized database. Typically the intervals between positions or pings are one or two hours (Hintzen et al. 2012). Based on the vessel ID, time and position, VMS data can be linked to logbook registrations. Logbooks register the amount of fish caught per species per haul. In addition, information on the gear type and size, mesh size and engine power of the ship are provided. By linking VMS and logbook data, it is possible to estimate the fishing frequency of a specific part of the Dutch fishing fleet in a specific area. Based on speed, it is estimated whether a vessel is fishing or not. Only the VMS pings where fishing activity is supposed were used for further analysis of the SSC fleet.

For illustrative purposes, figures are made based on the aggregated effort (fishing hours) per grid cell (1/16 ICES rectangle). The numbers presented in the graphs are based on VMS pings that are truly within the Plaice Box. 


\section{$4 \quad$ Results}

The highest effort of the SSC fishery can be found in the Southern part of the North Sea (Figure 1). Some parts of the Plaice Box seem to be used by the SSC fishery relatively frequent although some of these are gridcells on the outer edges of the Plaice Box which could mean that most of the fishery was done just outside the Plaice Box.

\section{Fishing Effort Flyshoot 2010-2019}

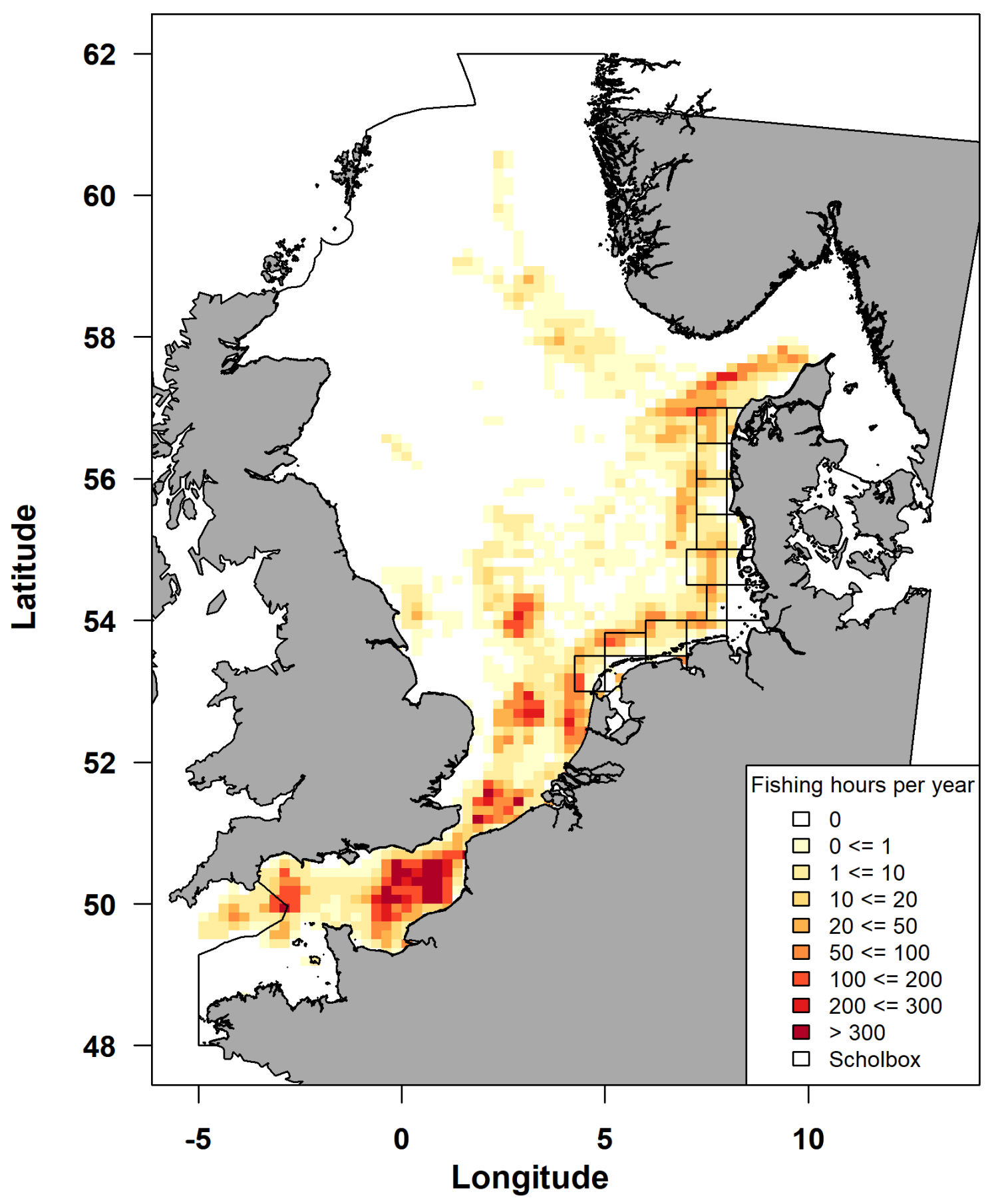


Fishing Effort Flyshoot 2010-2019 Plaice box

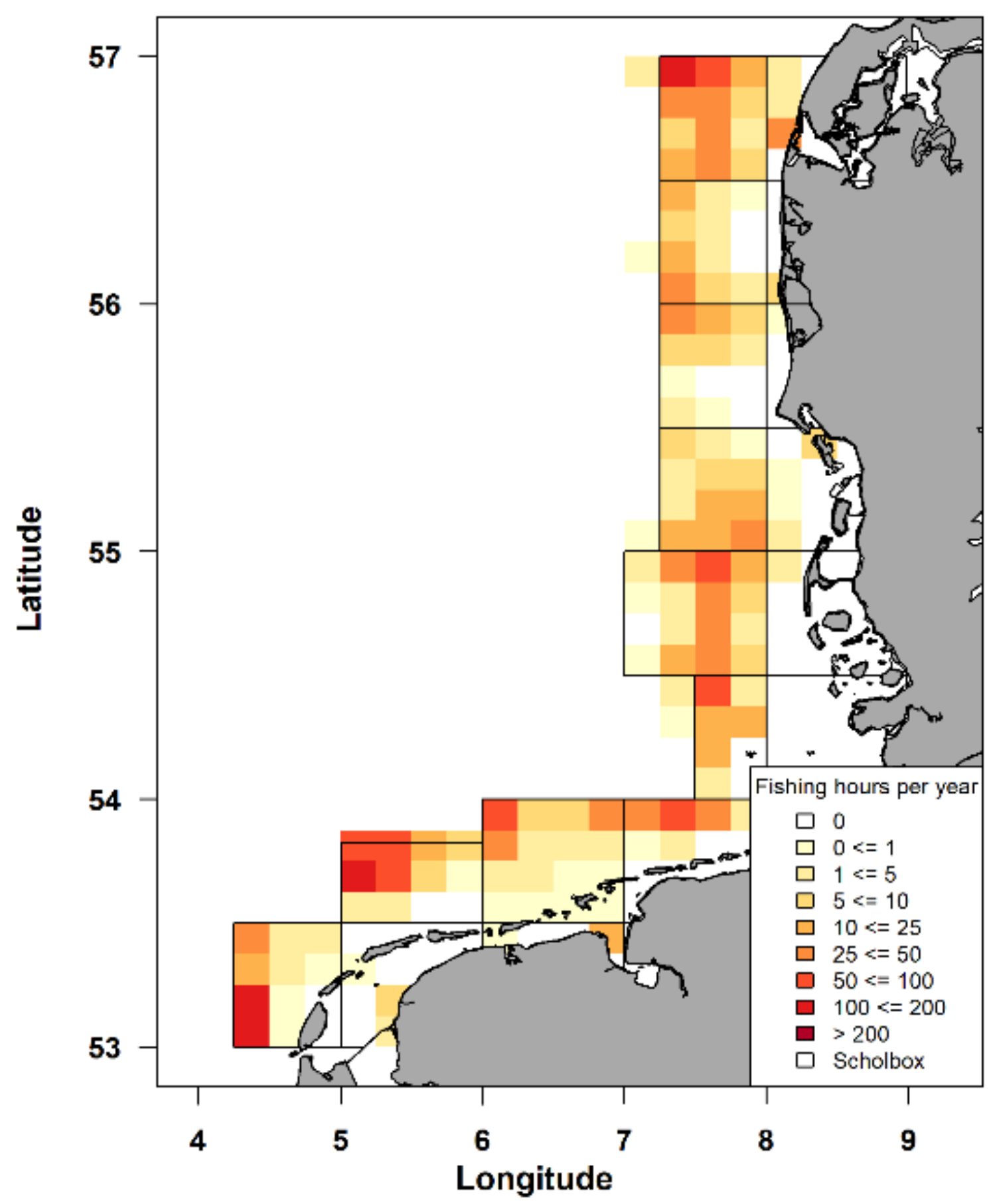

Figure 1 Effort of the Dutch flyshoot (SSC) fishery per year over the years 2010-2019 in the Greater North Sea (upper) and the Plaice Box (lower). Colours indicate the number of fished hours per year per gridcell (1/16 ICES rectangle). The Plaice Box and Greater North Sea are indicated with black lines. Note the different scales of the legends. 
The average number of flyshoot vessels per year that fish within the Plaice Box is 13, ranging from 10 in 2010 to 16 in 2019 (Table 1).

Table 1 Number of flyshoot vessels per year fishing in the Plaice Box.

\begin{tabular}{ll} 
Year & Number of vessels \\
\hline 2010 & 10 \\
2011 & 12 \\
2012 & 13 \\
2013 & 13 \\
2014 & 13 \\
2015 & 12 \\
2016 & 14 \\
2017 & 14 \\
2018 & 16 \\
2019 & 16 \\
\hline
\end{tabular}

To illustrate the total catch per year per species, only species that consisted for $1 \%$ or more of the total catch were selected. Based on these data, the SSC fleet lands mainly tub gurnard, followed by dab and plaice (Figure 2).

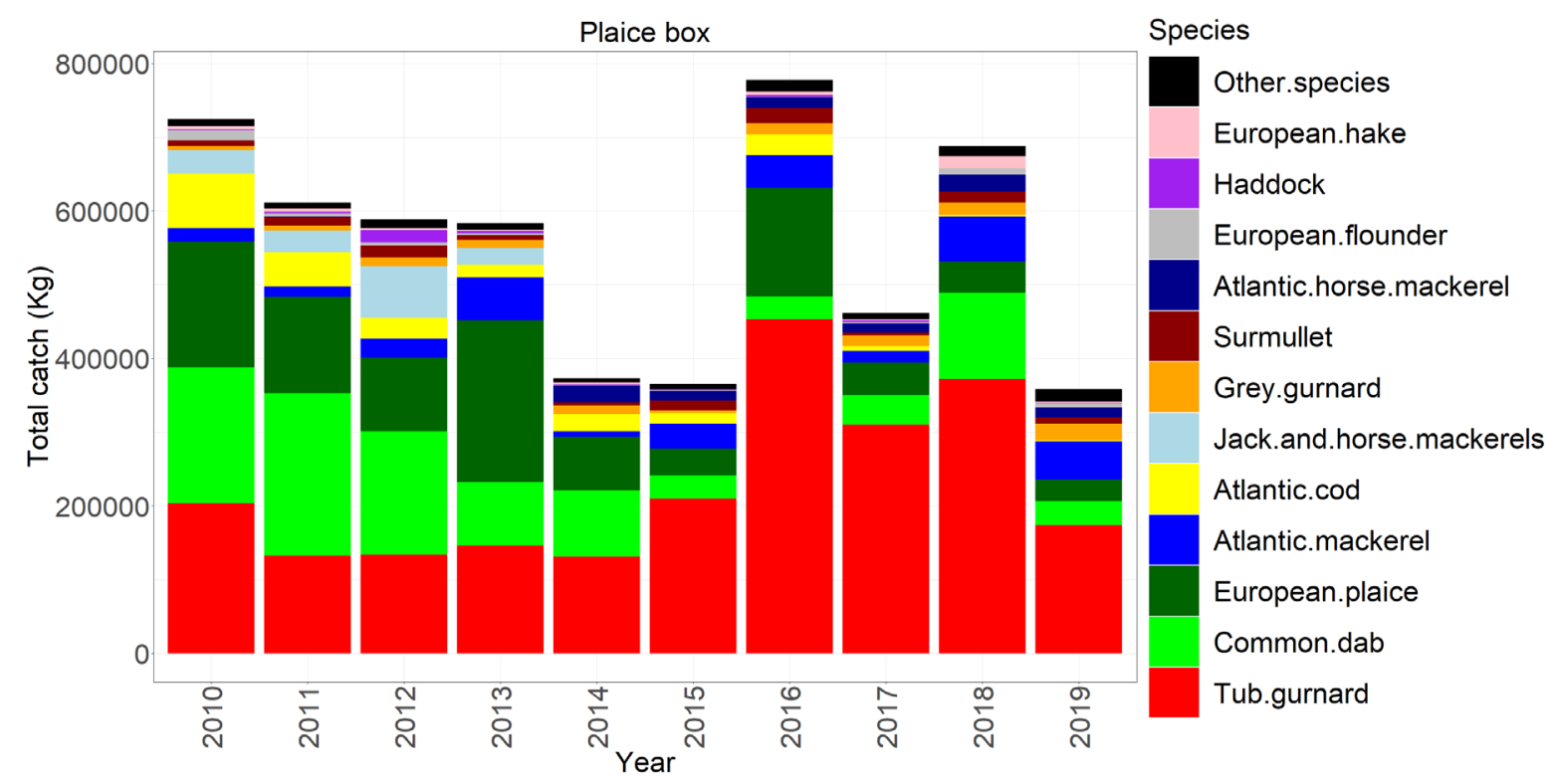

Figure 2 Total catch $(\mathrm{Kg})$ of the species that form a minimum of $1 \%$ of the total flyshoot (SSC) catches per year in the Plaice Box. On average, these species make up $99 \%$ of the complete catch. 
To estimate the percentage of each species caught per haul, only hauls with a total amount of more than $1 \mathrm{~kg}$ were selected. This shows that in percentages, tub gurnard, plaice and dab are caught the most (Figure 3). The average percentage of plaice and sole per year is $14.6 \%$ of the total catch where the vast majority consists of plaice and only $0.003 \%$ consists of sole. The relative high percentage of other species in 2019 mainly consists of squids.

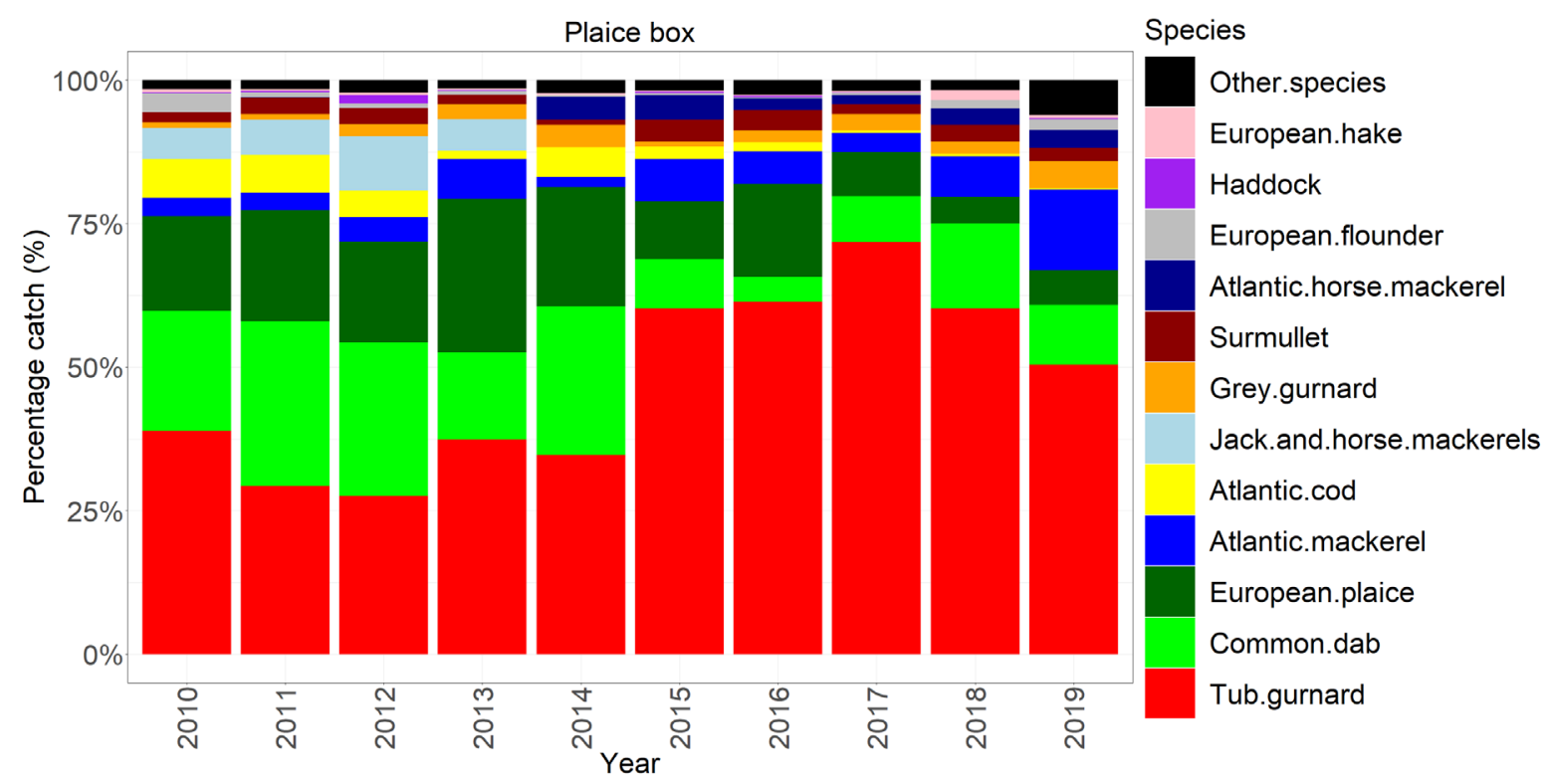

Figure 3 Percentage of each species that form a minimum of $1 \%$ of the total flyshoot (SSC) catches per year in the Plaice Box. On average, these species make up $99 \%$ of the complete catch. 


\section{Conclusions}

The largest effort of the flyshoot fishery is in the southern part of the Greater North Sea. The flyshoot fishery is also active in the Plaice Box with the largest effort at the outer periphery of the Plaice Box. The catches of the flyshoot fishery mainly consist of tub gurnard, dab and plaice. The percentage of plaice (and sole) per year compared to the total catch is $14.6 \%$. 


\section{Quality Assurance}

Wageningen Marine Research utilises an ISO 9001:2015 certified quality management system. This certificate is valid until 15 December 2021. The organisation has been certified since 27 February 2001. The certification was issued by DNV GL. 


\section{References}

Hintzen N. T. Bastardie F. Beare D. Piet G. J. Ulrich C. Deporte N. Egekvist J. et al. 2012 . VMStools: open-source software for the processing, analysis and visualisation of fisheries logbook and VMS data. Fisheries Research, 115-116: $31-43$.

Van der Reijden, K.J., R. Verkempynck, R.R. Nijman, S.S. Uhlmann, A.T.M. van Helmond and A. Coers, 2014. Discard self-sampling of Dutch bottom-trawl and seine fisheries in 2013. CVO Report 14.007. 


\section{Justification}

Report C009/21

Project Number: 4313200014

The scientific quality of this report has been peer reviewed by a colleague scientist and a member of the Management Team of Wageningen Marine Research

Approved: $\quad$ Niels Hintzen

Senior Researcher

Signature:

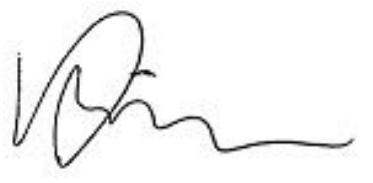

Date: $\quad 9$ February 2021

Approved: $\quad$ Drs. J. Asjes

Maneger Integration

Signature:

Date:

9 February 2021 
Wageningen Marine Research

T +31(0)317480900

E: marine-research@wur.nl

www.wur.eu/marine-research

Visitors' address

- Ankerpark 271781 AG Den Helder

- Korringaweg 7, 4401 NT Yerseke

- Haringkade 1, 1976 CP IJmuiden
With knowledge, independent scientific research and advice, Wageningen Marine Research substantially contributes to more sustainable and more careful management, use and protection of natural riches in marine, coastal and freshwater areas.

Wageningen Marine Research is part of Wageningen University \& Research. Wageningen University \& Research is the collaboration between Wageningen University and the Wageningen Research Foundation and its mission is: 'To explore the potential for improving the quality of life' 